\title{
Publication Under the Freedom of Information Act of Statements of General Policy and Interpretations of General Applicability
}

The Freedom of Information Act requires every federal agency to "publish in the Federal Register for the guidance of the public ... statements of general policy or interpretations of general applicability formulated and adopted by the agency." Another provision of the Act provides that each agency "make available for public inspection ... those statements of policy and interpretations which have been adopted by the agency and are not published in the Federal Register."2 Courts and commentators have generally

15 U.S.C. $\S 552(a)(1)(D)$ (1976). Section 552(a)(1) provides:

Each agency shall make available to the public information as follows:

(1) Each agency shall separately state and currently publish in the Federal Register for the guidance of the public-

(A) descriptions of its central and field organization and the established places at which the employees (and in the case of a uniformed service, the members) from whom, and the methods whereby, the public may obtain information, make submittals or requests, or obtain decisions;

(B) statements of the general course and method by which its functions are channeled and determined, including the nature and requirements of all formal and informal procedures available;

(C) rules of procedure, descriptions of forms available or the places at which forms may be obtained, and instructions as to the scope and contents of all papers, reports, or examinations;

(D) substantive rules of general applicability adopted as authorized by law, and statements of general policy or interpretations of general applicability formulated and adopted by the agency; and

(E) each amendment, revision or repeal of the foregoing.

The section's sanction provision is quoted in note 49 infra.

${ }^{2} 5$ U.S.C. $\S 552(a)(2)(B)$ (1976). Section 552(a)(2) provides:

Each agency, in accordance with published rules, shall make available for public inspection and copying-

(A) final opinions, including concurring and dissenting opinions, as well as orders, made in adjudication of cases;

(B) those statements of policy and interpretations which have been adopted by the agency and are not published in the Federal Register; and

(C) administrative staff manuals and instructions to staff that affect a member of the public;

unless the materials are promptly published and copies offered for sale. . . A final order, opinion, statement of policy, interpretation, or staff manual or instruction that 
agreed that these provisions must be interpreted together, ${ }^{3}$ but have experienced difficulty in identifying precisely which policy statements and interpretations must be published. ${ }^{4}$

A series of recent $t^{5}$ court decisions has adopted a significantimpact test to determine whether publication is required under section $552(\mathrm{a})(1)(\mathrm{D}){ }^{6}$ This comment will argue that this test is inconsistent with the language of the statute, raises other problems of statutory construction, and is inconsistent with the intent of Congress. The comment will then analyze the statutory language and the relevant legislative history to determine the meaning of section 552(a)(1)(D)'s publication requirement and will propose an alternative guide to the meaning of the section that is consistent with the language, history, and purpose of the Act.

\section{The Emerging Significant-Impact Test}

Under section 552(a)(1)(D), statements of "general policy" and "interpretations of general applicability" must be published in the Federal Register; ${ }^{7}$ with respect to other policy statements and interpretations, section $552(\mathrm{a})(2)(\mathrm{B})$ requires only that they be "available for public inspection and copying." Whether a policy statement or interpretation must be published depends, therefore,

affects a member of the public may be relied on, used, or cited as precedent by an agency against a party other than an agency only if-

(i) it has been indexed and either made available or published as provided by this paragraph; or

(ii) the party has actual and timely notice of the terms thereof.

${ }^{3}$ See, e.g., Lewis v. Weinberger, 415 F. Supp. 652, 659 (D.N.M. 1976); Tax Analysts \& Advocates v. IRS, 362 F. Supp. 1298, 1303-04 (D.D.C. 1973), modified on other grounds, 505 F.2d 350 (D.C. Cir. 1974); 1 K. Davis, Administrative Law Treatise 341 (2d ed. 1978); Note, The Freedom of Information Act: A Seven Year Assessment, 74 Colum. L. REv. 895, 899 (1974).

" One commentator has concluded that the question "probably cannot be answered except in vague terms." $1 \mathrm{~K}$. DAvis, supra note 3 , at 341 .

- Even though the publication requirement appeared in the public-information section of the Administrative Procedure Act as originally enacted in 1946, see note 53 infra, the section was amended in 1966 with the passage of the Freedom of Information Act. The deletion of certain restrictions on the publication requirement, see text and notes at notes 53-54 infra, may explain the recent origin of this test.

- United States v. Mowat, 582 F.2d 1194, 1200 (9th Cir.), cert. denied, 439 U.S. 967 (1978); Appalachian Power Co. v. Train, 566 F.2d 451, 455 (4th Cir. 1977); Anderson v. Butz, 550 F.2d 459, 463 (9th Cir. 1977); Hark v. Dragon, 477 F. Supp. 308, 315 (D. Vt. 1979); Aiken v. Obledo, 442 F. Supp. 628, 653 (E.D. Cal. 1977); Dean v. Butz, 428 F. Supp. 477,480 (D. Hawaii 1977); Lewis v. Weinberger, 415 F. Supp. 652, 659 (D.N.M. 1976).

3 See note 1 supra.

- See note 2 supra. 
on the meaning of the word "general" or the phrase "of general applicability." In five recent cases, the Fourth and Ninth Circuits and several district courts have used a significant-impact test to determine whether a policy statement or interpretation is general or of general applicability. ${ }^{10}$

This test was first formulated by the district court in Lewis $v$. Weinberger. ${ }^{11}$ The Indian Health Service had sent a policy memorandum to agency personnel indicating that certain medical benefits were unavailable to "off-reservation" Indians. ${ }^{12}$ The plaintiffs challenged the agency's application of this policy to them, arguing that the agency's failure to publish the memorandum made it ineffective. ${ }^{13}$ The court noted that the obligation to publish policy statements and interpretations depends on the meaning of the

- Courts and commentators have agreed that the meaning of these terms is crucial. See, e.g., Lewis v. Weinberger, 415 F. Supp. 652, 659 (D.N.M. 1976); 1 K. Davis, supra note 3, at 343 ("Congress has done no more than provide a framework which depends mainly on giving meaning to the word 'general.' ").

10 See cases cited note 6 supra.

11415 F. Supp. 652 (D.N.M. 1976). The Lewis court cited, id. at 659, two decisions as precedent for the use of a significant-impact test. Hogg v. United States, 428 F.2d 274 (6th Cir. 1970), cert. denied, 401 U.S. 910 (1971); Anderson v. Butz, 428 F. Supp. 245 (E.D. Cal. 1975), aff'd, 550 F.2d 459 (9th Cir. 1977). Analysis of these two cases, however, indicates that neither should be regarded as precedent for the use of a significant-impact test.

In Anderson, a Department of Agriculture "instruction" stated that HUD housing subsidies were "income" for purposes of the Food Stamp Program. The court held that this instruction was substantive, and that publication was required for substantive instructions in addition to those of general applicability. The court said that "statements of policy and interpretations not of general applicability or not affecting substantive rights of others outside the agency need not be published in the Federal Register." Id. at 250. The addition of the "substantive rights" consideration to the publication requirement of section $552(a)(1)(D)$ rested on two premises. First, an agency instruction with substantive impact is not an interpretive rule or general statement of policy within section 553(b)'s exemption from the notice-and-comment requirements. Second, publication under section 552(a)(1)(D) must be required for all agency actions for which notice and comment are due. Id. Thus, the Anderson court imported from section 553 an additional factor requiring publication; unlike Lewis, it did not define the "general applicability" language of section $552(a)(1)(D)$ in terms of impact.

In Hogg, the court misconstrued the statute, stating that "[u]nder the provisions of 5 U.S.C. $\& 552$, the requirement for publication attaches only to matters which if not published would adversely affect a member of the public." 428 F.2d at 274. See also Pasco, Inc. v. FEA, 525 F.2d 1391, 1405 (T.E.C.A. 1975) (quoting the Hogg test). As Professor Davis has noted, "the statute contains no such limitation." $1 \mathrm{~K}$. DAvis, supra note 3 , at 339 . The adverse-effect language appears in the sanction provision of the Act, but not in the publication requirement. See text and notes at notes $49-52$ infra.

12415 F. Supp. at 656.

13 Id. at 657-58. 
word "general" or the phrase "of general applicability,"14 and stated:

A policy statement is not qualified as "general" nor is an administrative interpretation deemed to be "of general applicability" if: (1) only a clarification or explanation of existing laws or regulations is expressed; and (2) no significant impact upon any segment of the public results. . . .

.. . [P]olicy or interpretive statements are deemed to fall within the scope of 552(a)(1)(D) requiring their publication, when they adopt new rules or substantially modify existing rules, regulations, or statutes and thereby cause a direct and significant impact upon the substantive rights of the general public or a segment thereof. ${ }^{15}$

Because the substantive rights of the Lewis plaintiffs were changed by the challenged memorandum, ${ }^{16}$ the court concluded that the memorandum was a "statement of general policy" within section $552(\mathrm{a})(1)(\mathrm{D})$. The court ordered the payment of the plaintiffs' medical expenses and enjoined further application of the unpublished standard. ${ }^{17}$

The Fourth and Ninth Circuits have added refinements to the test formulated by the Lewis court. In Anderson v. Butz, ${ }^{18}$ a Department of Agriculture "instruction" required the inclusion of rent subsidies as income for the purpose of determining eligibility for food stamps. ${ }^{19}$ The Ninth Circuit held that the "instruction," a mandatory change from existing practice, required publication because it had an immediate and direct impact on the substantive rights of the recipients. ${ }^{20}$ Although the Lewis and Anderson courts defined the test in terms of impact on substantive rights, the Fourth Circuit, in Appalachian Power Co. v. Train, ${ }^{21}$ held that agency statements have significant impact and must be published when "knowledge of [them] is needed to keep the outside interests

14 Id. at 659 .

15 Id.

${ }^{16}$ One of the plaintiffs had received benefits under prior agency standards. The memorandum deprived this plaintiff of the right to future benefits and changed the applicable standards for determining the future eligibility of the other plaintiff. Id. at 655-56.

${ }^{17}$ Id. at 661-62.

${ }^{18} 550$ F.2d 459 (9th Cir. 1977).

19 Id. at 460 .

20 Id. at 469.

${ }^{21} 566$ F.2d 451 (4th Cir. 1977). 
informed of the agency's requirements in respect to any subject within its competence."22

Hark v. Dragon ${ }^{23}$ is the only reported case in which a court has used the significant-impact test to find publication unnecessary. The Regional Administrator of the Department of Labor had written a letter to Comprehensive Employment and Training Act ("CETA") employers recommending that they establish a maximum length for CETA employment. ${ }^{24}$ The federal district court held that publication was not required because the agency letter at issue was "not of such a nature that it affects the legal rights of [the] plaintiffs or any other persons, and is thus not within the scope of the publication requirement."25 The court stressed that the agency letter was "merely a recommendation," which the sponsors were "free to adopt or reject."26

The Appalachian Power, Anderson, and Lewis courts ${ }^{27}$ used the significant-impact test in an explicit attempt to give meaning to the statutory language. ${ }^{28}$ These courts did not, however, clearly articulate any sound reason for equating the test with the word "general" or the phrase "of general applicability." Moreover, analysis of the statutory language in question, other provisions of the statute, and the relevant legislative history will demonstrate that the significant-impact test should not be used in construing section 552(a)(1)(D)'s publication requirement.

22 Id. at 455 (quoting United States v. Hayes, 325 F.2d 307, 309 (4th Cir. 1963)). The plaintiffs challenged certain EPA regulations on the ground that the agency failed to publish through incorporation by reference a "Development Document." This document contained information relevant to the determination of what technology was required by the regulation. 566 F.2d at 454 .

${ }^{23} 477$ F. Supp. 308 (D. Vt. 1979).

24 Id. at 315.

$25 \mathrm{Id}$.

${ }^{26} I d$.

${ }^{27}$ The significant-impact test was also adopted by the district court in Dean v. Butz, 428 F. Supp. 477 (D. Hawaii 1977). A letter from the Department of Agriculture required the state of Hawaii's agency responsible for social services and housing to count housing security deposits provided to AFDC and general-assistance recipients in the state as income for food-stamp purposes. Since the clarification meant increased payments by recipients for food stamps, a "substantial impact upon . . . limited budgets," it was of general applicability and publication was required by section $552(\mathrm{a})(1)(\mathrm{D})$. Id. at 480 .

${ }^{28}$ See Appalachian Power Co. v. Train, 566 F.2d 451, 455 (4th Cir. 1977); Anderson v. Butz, 550 F.2d 459, 463 (9th Cir. 1977); Lewis v. Weinberger, 415 F. Supp. 652, 659 (D.N.M. 1976). See also Aiken v. Obledo, 442 F. Supp. 628, 653 (E.D. Cal. 1977); 1 K. Davis, supra note 3, at 343. In Hark v. Dragon, 477 F. Supp. 308, 315 (D. Vt. 1979), the court relied on cases that had construed the language of the statute. The court did not, however, explicitly attempt to give meaning to the statutory language. $I d$. at 315 . 


\section{A Critique of the Significant-Impact Analysis}

The significant-impact test can be criticized on several levels. First, the test is inconsistent with the plain language of the statute. Second, if the test is used to construe the word "general" and the phrase "of general applicability" in section 552(a)(1)(D), problems arise in the construction of other parts of the statute. Third, the legislative history indicates that Congress did not intend to enact a significant-impact test in section $552(\mathrm{a})(1)(\mathrm{D})$.

\section{A. The Statutory Language}

Although the significant-impact test was developed as an explicit attempt to define the statutory terms "general" and "of general applicability" in section $552(\mathrm{a})(1)(\mathrm{D}),{ }^{28}$ "the idea of impact cannot be extracted from the word general." 30 Indeed, the significant-impact test is both too broad and too narrow as a measure of general applicability.

The significant-impact test does not provide sufficient guidance for determining which agency statements need only be made available, rather than published, because they are not of general applicability. An agency pronouncement applicable to only one person may have a significant substantive impact on that individual. Although it is unlikely that a court using the Lewis test would require publication of such a pronouncement, the test would seem to require publication, and is therefore overbroad.

On the other hand, statements of general policy and interpretations of general applicability should be published, even if such statements and policies do not affect legal rights. In Hark, for example, the letter to CETA employers expressed a general agency policy, and the plaintiffs lost their jobs as a result of that policy. ${ }^{31}$ Yet, the Court held that publication of the policy was not necessary because there had been no substantive impact on individual rights. The program participants had no legal right to continued

28 See note 1 supra.

so $1 \mathrm{~K}$. Davis, supra note 3, at 344. Professor Davis goes on to suggest that impact "can be extracted from what Congress would have intended by 'general' if it had expressed itself on the problem before the court," referring to the Lewis opinion, which he found "conservatively creative." Id. at 343 . Yet, as will be shown, see text and notes at notes 78-83 infra, there is no need for conservative creativity or hypothesizing to determine congressional intent.

31 Hark v. Dragon, 477 F. Supp. 308, 315 (D. Vt. 1979). 
employment, and the agency "recommendation" was not binding on the employers. ${ }^{32}$

Thus, there seems to be no logical relationship between impact and the term "general" or the phrase "of general applicability." Given the incompatibility of the significant-impact test with the language of section 552(a)(1)(D), the continued judicial application of the test is indefensible.

\section{B. Statutory Construction Problems}

When the word "general" and the phrase "of general applicability" in section 552(a)(1)(D) are construed in terms of the significant-impact test, two additional problems of statutory construction arise. First, a redundancy is created within section 552(a)(1)(D) itself. Second, the construction of section $552(\mathrm{a})(1)(\mathrm{D})$ becomes inconsistent with the construction given section $553(\mathrm{~b})(\mathrm{A})$.

1. The Section 552(a)(1)(D) Redundancy. Section $552(a)(1)(D)$ requires publication not only of "statements of general policy or interpretations of general applicability," but also of "substantive rules of general applicability." 33 The courts that have adopted the significant-impact test have done so in construing "interpretations of general applicability."34 When the significant-impact meaning of "general applicability" is applied to "substantive rules of general applicability," that phrase becomes internally redundant.

Substantive rules, in other contexts, have generally been interpreted to mean rules having an impact. ${ }^{35}$ Yet, under the significant-impact analysis of Lewis and other courts, the phrase "of general applicability" also connotes impact. Thus, all substantive rules are, under such an analysis, substantive rules of general applicability. It is doubtful, however, that Congress meant to require the publication of all substantive rules. To read in such an intent, one must assume that Congress considered "of general applicability"

32 Id.

33 See note 1 supra.

34 See cases cited note 28 supra.

3s See, e.g., McDonnell Douglas Corp. v. Marshall, 465 F. Supp. 22, 25 (E.D. Mo. 1978) (a statement is substantive if " it creates or changes existing rights and obligations' ") (quoting Reynolds Metals Co. v. Rumsfeld, 417 F. Supp. 365, 372 (E.D. Va. 1976)); Reynolds Metals Co. v. Rumsfeld, 417 F. Supp. 365, 372 (E.D. Va. 1976), aff'd in relevant part, 564 F.2d 663 (4th Cir. 1977), cert. denied, 435 U.S. 995 (1978). See also Saint Francis Memorial Hosp. v. Weinberger, 413 F. Supp. 323, 329 (N.D. Cal. 1976). 
and "substantive" as redundant, and yet combined them in the phrase "substantive rules of general applicability."36

2. The Section 552(a)(1)(D)-553(b)(A) Inconsistency. Section $553(\mathrm{~b})(\mathrm{A})^{37}$ of the Administrative Procedure Act ("APA"), ${ }^{38}$ exempts from certain notice-and-comment requirements "interpretative rules [and] general statements of policy." Reading that section in conjunction with section 552(a)(1)(D), one would suppose that "statements of general policy or interpretations of general applicability" requiring publication under the latter section would be exempt from notice-and-comment requirements under section $553(\mathrm{~b})(\mathrm{A})$. All "statements of general policy" seem logically to fall within section $553(\mathrm{~b})(\mathrm{A})$ 's exemption for "general statements of policy," 39 and under the APA definitions, "interpretations of general applicability" are included in section 553(b)(A)'s exemption for "interpretative rules." 40 Yet the courts that have adopted the

${ }^{36}$ The statutory construction problem is strikingly illustrated in 2 B. MEZINES, J. STEIN \& J. GrufF, Administrative Law (1979). While using the significant-impact test to define interpretations of general applicability, $i d$. at $8-33$ to 34 , the treatise defines substantive rules of general applicability as "agency directives or policies which relate to the public as a whole, including the affected party. Rules relating to just one party and a particular set of circumstances are not considered to be generally applicable." Id. at 8-27.

${ }^{37} 5$ U.S.C. $\S 553(\mathrm{~b})(\mathrm{A})$ (1976):

(b) General notice of proposed rule making shall be published in the Federal Register, unless persons subject thereto are named and either personally served or otherwise have actual notice thereof in accordance with law. . . .

Except when notice or hearing is required by statute, this subsection does not apply-

(A) to interpretative rules, general statements of policy, or rules of agency organization, procedure, or practice .... .

${ }^{38}$ Id. $\S \S 551-552,553-559,701-706,1305,3105,3344,5362,7521$.

30 The terms "general statements of policy" and "statements of general policy," however, may not be equivalent. The exemption in section $553(\mathrm{~b})(\mathrm{A})$ for "general statements of policy" apparently applies to all policy statements. Congress cannot have intended to exempt only general policy statements and to require notice and comment for other, less important, "non-general" policy statements. See Koch, Public Procedures for the Promulgation of Interpretative Rules and General Statements of Policy, 64 GEo. L.J. 1047, 1051 n.17 (1976). Section 552(a)(1)(D), on the other hand, requires publication of "statements of general policy." Presumably, some agency policy statements would not be "statements of general policy" and would not require publication. See $1 \mathrm{~K}$. DAvis, supra note 3, at 343 .

This analysis is not inconsistent with the discussion in text. Since all policy statements are included in the section 553(b)(A) exemption, it necessarily follows that those policy statements considered "statements of general policy" under section $552(a)(1)(D)$ are "general statements of policy" under section $553(\mathrm{~b})(\mathrm{A})$.

${ }^{10}$ Under the relevant APA definition, rules include interpretations. 5 U.S.C. $\S 551(4)$ (1976) (" 'rule' means the whole or part of an agency statement of general or particular applicability and future effect designed to implement, interpret, or prescribe law or policy"). Interpretations adopted and formulated by the agency are, therefore, equivalent to interpretive rules. 
significant-impact test for interpreting the publication requirement of section $552(\mathrm{a})(1)(\mathrm{D})$ have not given a consistent construction to section $553(\mathrm{~b})(\mathrm{A})$.

Courts have adopted two tests to determine whether an interpretation or policy statement is exempt under section 553(b)(A): the legal-effects test and the substantive-impact test."1 The weight of authority supports the proposition that a statement is not an interpretation exempt from section 553's rulemaking requirements if it has a binding legal effect. A strong minority position, however, suggests that the exemption depends on whether an interpretation has any impact on the substantive rights of those concerned. ${ }^{2}$ Under the significant-impact test, section $552(a)(1)(D)$ provides that an agency must publish interpretations that have a substantive impact. ${ }^{43}$ Under either construction of section 553, however, an agency "interpretation" having significant impact is generally not an interpretation at all, but a legislative (or substantive) rule requiring notice and comment. ${ }^{44}$

The Lewis case itself illustrates the inconsistency in the context of policy statements. In Lewis, the court found that publication of the policy statement was required under section 552 , but also found that section 553 required notice and comment. ${ }^{45}$ The court first found the memorandum in question to be "a 'statement of general policy' within the meaning of 552(a)(1)."46 The court then found that the same memorandum was neither "an 'interpretive rule' nor a 'general statement of policy' within the meaning of

It does not follow, however, that all interpretive rules under section $553(\mathrm{~b})(\mathrm{A})$ are necessarily "interpretations of general applicability" under section 552(a)(1)(D). Some interpretive rules might be only of particular applicability. All "interpretations of general applicability" under section 552(a)(1)(D) would, however, be interpretive rules under section 553(b)(A). Thus, any interpretive rule of general applicability would require publication in the Federal Register and would be exempt from the notice-and-comment requirements under section 553(b)(A).

11 Compare Pacific Gas \& Elec. v. FPC, 506 F.2d 33 (D.C. Cir. 1974) (legal-effects test) with Pharmaceutical Mfrs. Ass'n v. Finch, 307 F. Supp. 858 (D. Del. 1970) (substantiveimpact test). See also 1 K. DAvis, supra note 3, at 193-200; Asimow, Public Participation in the Adoption of Interpretative Rules and Policy Statements, 75 Mich. L. REv. 520 (1977).

12 See Asimow, supra note 41, at 545.

${ }^{43}$ See, e.g., Anderson v. Butz, 550 F.2d 459 (9th Cir. 1977).

11 One court suggested, however, that for purposes of section 552(a)(1), an interpretation may have significant impact although it lacks binding effect. Aiken v. Obledo, $442 \mathrm{~F}$. Supp. 628, 653 (E.D. Cal. 1977). But see Anderson v. Butz, 550 F.2d 459, 463 (9th Cir. 1977); Hark v. Dragon, 477 F. Supp. 308, 315 (D. Vt. 1979). Under such an analysis, the statement in text would not be true.

46415 F. Supp. at $659,661$.

t6 Id. at 659 . 
section 553(b)(A)"; ${ }^{47}$ no attempt was made to explain this anomaly..$^{48}$

Thus, the significant-impact test is not only inconsistent with the publication standard imposed by Congress; its use also raises problems in the consistent, coherent interpretation of both sections 552(a)(1)(D) and 553(b)(A). These factors suggest that Congress did not intend to impose a significant-impact standard in section $552(a)(1)(D)$. This conclusion receives additional support from the manner in which Congress dealt with impact in the context of section 552.

\section{Congressional Attention to Impact}

Despite the incompatibility of the significant-impact test with the words of the statute, it is still possible that Congress, unaware of the inconsistency, sought to impose such a test when it used the word "general" and the phrase "of general applicability." Both the sanction provision applicable to section 552(a)(1)(D) and the 1966 amendments to section 552(a)(1)(D) indicate, however, that Congress did not intend to impose a significant-impact test in section $552(\mathrm{a})(1)(\mathrm{D})$.

1. The Sanction Provision of Section 552(a)(1). Section 552 (a)(1) specifies the appropriate sanction for failure to publish any of the items described in subsections $552(\mathrm{a})(1)(\mathrm{A})$ to (E). ${ }^{48} \mathrm{Un}$ -

47 Id. at 661.

${ }^{48}$ See id. See also Anderson v. Butz, 428 F. Supp. 245, 249-50 (E.D. Cal. 1975) (agency statement held to be either an interpretation of general applicability or a general statement of policy under section 552(a)(1)(D), but not an interpretive rule or general statement of policy under section 553(b)(A)), aff'd, 550 F.2d 459 (9th Cir. 1977).

49 The sanction provision of section $552(\mathrm{a})(1)$ provides:

Except to the extent that a person has actual and timely notice of the terms thereof, a person may not in any manner be required to resort to, or be adversely affected by, a matter required to be published in the Federal Register and not so published. For the purpose of this paragraph, matter reasonably available to the class of persons affected thereby is deemed published in the Federal Register when incorporated by reference therein with the approval of the Director of the Federal Register.

5 U.S.C. $\$ 552(a)(1)$ (1976). The "resort to" clause of the sanction provision has been interpreted to refer to agency procedural requirements. U.S. DeP'T OF JUSTICE, ATtoRnEY GENeral's Memorandum on the Public Information Section of the Administrative ProceDURE ACT 11 (1967) [hereinafter cited as Attorney General's Memorandum], reprinted in Subcommitree on Administrative Practice and Procedure of the Senate Judiciary Comm., Freedom of Information Act Sourcebook, S. Doc. No. 93-82, 93d Cong., 2d Sess. 210 (1974) [hereinafter cited as FOIA SouRcEBook] ("[T]he previous provisions relating to failure to publish required materials applied only to materials concerning organization and procedure. It provided that no person shall be required to resort to organization or procedure not published in the Federal Register."). The "adversely affect" language was included 
less a person has received "actual and timely notice" of the terms of an agency statement, he cannot be "required to resort to, or be adversely affected by, a matter required to be published in the Federal Register and not so published."50 This clear statement of an impact test in the sanction provision ${ }^{51}$ applicable to section $552(a)(1)(D)$ indicates that Congress knew how to frame such a test. If Congress had meant to impose such a test in section $552(a)(1)(D)$, it would not have done so by the use of words bearing no logical relation to impact. ${ }^{52}$

by the 1966 amendments to give agencies an "added incentive" to publish statements of general applicability that were more substantive in nature. See H.R. REP. No. 1497, 89th Cong., 2d Sess. 7 (1966), reprinted in FOIA SourceBook, supra, at 28.

so See note 49 supra. The sanction provision does not provide that unpublished pronouncements are void. Congress specifically intended to avoid such a result. In the Senate Committee Report discussing the same language in a prior version of the bill, the Committee stated that the sanction required that unpublished standards be of "no force and effect." S. REP. No. 1219, 88th Cong., 2d Sess. 12 (1964), reprinted in FOIA Sourcebook, supra note 49 , at 97 . The subsequent Committee Report, however, deleted this language so as not to provide for voidness when the agency statement conferred benefits on the persons affected. AtTorney General's Memorandum, supra note 49, at 11-12, reprinted in FOIA Sourcebook, supra note 49 , at $210-11$. This legislative history suggests that the sanction provision should be broadly construed. But see Neighborhood Legal Servs. v. Legal Servs. Corp., 466 F. Supp. 1148, 1154 (D. Conn. 1979) (interpreting Congress's rejection of the voidness sanction to construe the provision narrowly).

${ }^{31}$ The courts have not agreed on the precise nature of this test. In the majority of cases, the courts have struck down agency action because application of the unpublished standard "adversely affected" the parties. See, e.g., Anderson v. Butz, 550 F.2d 459, 463 (9th Cir. 1977); Lewis v. Weinberger, 415 F. Supp. 652, 661 (D.N.M. 1976). Other courts, however, have held that the appropriate standard is not whether the substance of the unpublished standard causes an "adverse effect," but whether the agency's failure to publish causes an adverse effect. Pesikoff v. Secretary of Labor, 501 F.2d 757, 763 n.12 (D.C. Cir.), cert. denied, 419 U.S. 1038 (1974); Neighborhood Legal Servs. v. Legal Servs. Corp., 466 F. Supp. 1148, 1154 (D. Conn. 1979). See, e.g., Lewis-Mota v. Secretary of Labor, 337 F. Supp. 1289, 1296 (S.D.N.Y.), rev'd on other grounds, 469 F.2d 478 (2d Cir. 1972).

The statutory language does not directly support a rule requiring the challenging party to have been harmed by the failure to publish. The sanction provision is, however, inapplicable when the person has "actual and timely notice" of the unpublished standard. And under Lewis-Mota, notice is said to be timely when the person has not been adversely affected by the failure to publish. This definition of timeliness thus sharply limits the scope of the sanction provision. Other courts have refused to find timely notice in similar circumstances. See, e.g., Anderson v. Butz, 550 F.2d 459, 463 (9th Cir. 1977) (finding that notification when the instruction took effect could not be the actual, timely notice intended by Congress). See also Morton v. Ruiz, 415 U.S. 199 (1974).

${ }_{B 2}$ That Congress supplied a sanction only in those situations in which impact could be demonstrated does not mean that Congress meant to require publication of interpretations and policy statements only in those same situations. On the contrary, the original sanction provision was not coextensive with the publication requirement. See ATrorney General's Memorandum, supra note 49, at 11, reprinted in FOIA Sourcebook, supra note 49, at 210. Indeed, the House Report on the 1966 amendments, which added the "adversely affect" language, stated that the sanction would provide "[a]n added incentive for agencies to pub- 
2. The 1966 Amendments. Section 552(a)(1)(D) originally required publication of "statements of general policy or interpretations formulated and adopted by the agency for the guidance of the public."'ss The courts read this phrase as a limitation, concluding that an agency statement need not be published unless it was a "governmental plan or procedure which the public is required to obey or with which it is to avoid conflict." Under this reasoning, a statement fell within the publication requirement only if it had impact on substantive rights. Mere "interest to the public in any way" was not enough to require publication. ${ }^{\mathrm{ss}}$

Congress reacted by deleting the phrase from the body of the new subsection 552(a)(1)(D), and inserting it in the introductory clause, a statement of purpose applicable to all subsections of section $552(a)(1) .{ }^{56}$ The change was expressly designed "to require

lish" material under section 552(a)(1). H.R. REP. No. 1497, 89th Cong., 2d Sess. 7 (1966), reprinted in FOIA SourceBook, supra note 49 , at 28 . Accord, S. REP. No. 813 , 89th Cong., 1st Sess. 6 (1965), reprinted in FOIA Sourceвook, supra note 49, at 41 . The initial incentive, presumably, is provided by an agency's interest in complying with applicable law.

ss Administrative Procedure Act, ch. 324, § 3(a), 60 Stat. 238 (1946) (current version at 5 U.S.C. $§ 552(a)$ ) (emphasis added). The original provision read:

Except to the extent that there is involved (1) any function of the United States requiring secrecy in the public interest or (2) any matter relating solely to the internal management of an agency- (a) Every agency shall separately state and currently publish in the Federal Register . . . (3) substantive rules adopted as authorized by law and statements of general policy or interpretations formulated and adopted by the agency for the guidance of the public, but not rules addressed to and served upon named persons in accordance with law. No person shall in any manner be required to resort to organization or procedure not so published.

Id. (emphasis added).

It might be noted that the current publication and availability provisions also require "adopt[ion] by the agency." The only case to consider directly whether a statement had been adopted by the agency is Tax Analysts \& Advocates v. IRS, 362 F. Supp. 1298 (D.D.C. 1973), modified on other grounds, 505 F.2d 350 (D.C. Cir. 1974). The court rejected a narrow construction of this requirement, reasoning that "[t]he ordinary meaning of those words reaches any interpretation issued by the agency or its delegates acting within the scope of their authority." Id. at 1303. But see U.S. Dep'T of JUSTICE, AtTorney General's MemoRANDUM ON THE 1974 AMENDMENTS to the FreEdom of INFormation Act 16 (1975) (suggesting that the adoption requirement can only be met by statements and interpretations issued by the agency itself, or by a responsible official who has been empowered by the agency to make authoritative issuance). A narrow construction of this requirement may be contrary to the spirit of the Act. See $1 \mathrm{~K}$. Davis, supra note 3, at 356-58.

${ }^{54}$ Brownell v. Schering Corp., 129 F. Supp. 879, 905 (D.N.J. 1955), aff'd, 228 F.2d 624 (3d Cir.), cert. denied, 351 U.S. 954 (1956). Accord, Airport Comm'n v. CAB, 300 F.2d 185, 188 (4th Cir. 1962).

ss Brownell v. Schering Corp., 129 F. Supp. 879, 905 (D.N.J. 1955), aff'd, 228 F.2d 624 (3d Cir.), cert. denied, 351 U.S. 954 (1956).

so Compare the original statute, see note 53 supra, with the text of section 552(a)(1) as it is currently codified, see note 1 supra. 
agencies to disclose general policies which should be known to the public, whether or not they are adopted for public guidance." ${ }^{\text {"57 }}$ An early Senate report explained that this amendment was intended to change "the phrase 'for guidance of the public' . . . from a limitation ... to a descriptive phrase applicable to all matter being published in the Federal Register."

When Congress rejected the public-guidance clause as a limitation on the publication requirement, it tacitly disapproved judicial attempts to make significant impact a determining factor. In one recent case, Neighborhood Legal Services $v$. Legal Services Corp., ${ }^{58}$ the federal district court correctly noted that section $552(a)(1)(D)$ "recognizes that guidance of the public is achieved by publication of all policies of general applicability, not only those that regulate or supply 'guidance' to the public."60 The court found the agency action generally applicable and ordered publication without invoking the significant-impact test. ${ }^{61}$

Other courts, however, have continued to view the phrase as a limitation rather than a statement of purpose. For example, in Pasco, Inc. v. $F E A{ }^{62}$ the court relied on cases decided prior to the amendments in finding that publication of a rule of procedure was not required under section $552(\mathrm{a})(1)(\mathrm{C})$; the rule was "not designed for the guidance of the public because it in no way affects any steps which interested parties must take or not take in order to obtain, or review, action by the Commission." ${ }^{33}$ The effect of the 1966 amendments, as interpreted by the Pasco court, is directly contrary to congressional intent: instead of transforming the phrase "for the guidance of the public" from a limitation on sec-

\footnotetext{
B7 Attorney General's Memorandum, supra note 49, at 10, reprinted in FOIA SOURCEBOoK, supra note 49 , at 209.

s8 S. Rep. No. 1219, 88th Cong., 2d Sess. 3 (1964), reprinted in FOIA Sourcebook, supra note 49 , at 88 (emphasis added).

82 466 F. Supp. 1148 (D. Conn. 1979).

so Id. at 1153. The court also quoted the language from the AtTorney General's MrMORANDUM, supra note 49 , at 10 , reprinted in FOIA SoURCEBOoK, supra note 49 , at 209. See text at note 57 supra.

61466 F. Supp. at 1153.

62525 F.2d 1391 (T.E.C.A. 1975).

os Id. at 1405 (quoting T.S.C. Motor Freight Lines, Inc. v. United States, 186 F. Supp. 777, 786 (S.D. Tex. 1960), aff'd per curiam, 366 U.S. 419 (1961)). See also Pitts v. United States, 599 F.2d 1103, 1108 (1st Cir. 1979) (publication not required because " $[t]$ he purpose of publication in the Federal Register is public guidance"). Some recent decisions have cited pre-1966 cases as precedent without noting the statutory change. See, e.g., Hark v. Dragon, 477 F. Supp. 308, 315 (D. Vt. 1979) (citing Airport Comm'n v. CAB, 300 F.2d 185 (4th Cir. 1962)).
} 
tion $552(\mathrm{a})(1)(\mathrm{D})$ 's publication requirement to a purely descriptive phrase at the beginning of section 552(a)(1), the 1966 change makes the limitation applicable to all the subsections of 552(a)(1). The Pasco court's approach should be rejected. The 1966 amendments should be viewed as a clear rejection of a significant-impact test under section 552(a)(1)(D), and the appropriate publication standard should be determined by reference to the words of the statute construed in the light of their context and legislative history.

\section{The Intended Scope of the Publication Requirement}

\section{A. Statutory Language and Structure}

Section 552(a)(1)(D)'s language-“"statements of general policy or interpretations of general applicability"-focuses on the scope, rather than the effect, significant or otherwise, of the agency pronouncement. Thus, the statutory language suggests that publication is required when an interpretation or policy statement is relevant to many or most members of the public. Interpretations or policy statements not applicable to many members of the public do not require publication; availability under $552(\mathrm{a})(2)(\mathrm{B})$ is sufficient.

This reading of the statutory language is supported by the structure of section 552(a). Each subsection of 552(a)(1), the publication requirement, refers to matters of interest to the public at large, ${ }^{64}$ while the provisions of section $552(\mathrm{a})(2)$ require that information relevant to particular individuals be made available. ${ }^{65}$ Under subsection (a)(1), agencies must publish (A) organizational descriptions whereby "the public may obtain information, make submittals or requests, or obtain decisions," (B) statements of general course and method, (C) rules of procedure, and (D) substantive rules, interpretations, and policy statements of general applicability. Under section 552(a)(2), on the other hand, agencies must make available "for public inspection" (A) final opinions made in the adjudication of cases, (B) those statements of policy and interpretations not published in the Federal Register, and (C) "administrative staff manuals and instructions to staff that affect a member of the public." Adjudications by their very nature involve particular parties and specific factual situations. Statements of 
policy and interpretations not published in the Federal Register must necessarily be of particular, rather than general, applicability. Similarly, although staff manuals and instructions can be of general interest, the language used by Congress- "that affect a member of the public"-identifies relevance to a particular individual, as opposed to the general public. ${ }^{66}$ The statute thus distinguishes, in organization as well as in language, between agency pronouncements of general applicability and those of interest to particular individuals; no distinction is drawn in terms of the impact of the agency statement.

\section{B. Legislative History of the "General Applicability" Term}

The original APA publication requirement did not contain the words "general applicability." The legislative history indicates, however, that Congress considered the original wording equivalent to the current wording-and intended to fashion a standard that would focus on scope rather than impact.

The Senate version of the original APA required publication of all rules, ${ }^{67}$ but "rule" was defined to include only statements of general applicability. ${ }^{68}$ In subsequent amendments prior to passage, the definition of rules was changed to include those statements of particular applicability so as to cover "cases characterized by the shaping of broad policies upon the basis of masses of technical data," ${ }^{\prime 69}$ and the publication requirement was modified to exclude from publication those rules addressed to named persons. ${ }^{70}$

66 As originally enacted, this section required that administrative staff manuals and instructions to staff be made available to the public when they "affect any member of the public." Public Information Availability Act, Pub. L. No. 89-487, § 3(b), 80 Stat. 250 (1966) (current version at 5 U.S.C. § 552(a)(2) (1976)). This language, however, was modified in the process of codifying the statute. Neither the Committee Report nor the codification explains the change. H.R. REP. No. 125, 90th Cong., 1st Sess. (1967); S. Rep. No. 248, 90th Cong., 1st Sess. (1967). The difference does not seem significant.

${ }^{67}$ S. 7, 79th Cong., 1st Sess. § 3(a) (1945), reprinted in S. REP. No. 752, 79th Cong., 2d Sess. 33 (1945) and Senate Comm. on the Judiciary, Administrative Procedure Act Legislative History, S. Doc. No. 248, 79th Cong., 2d Sess. 219 (1946) [hereinafter cited as Legislative History].

Bs S. 7, 79th Cong., 1st Sess. § 21(c) (1945), reprinted in S. REP. No. 752, 79th Cong., 2d Sess. 32 (1945) and Legislative History, supra note 67, at 218.

"Giannane, "Rule Making," "Adjudication" and Exemptions Under the Administrative Procedure Act, 95 U. PA. L. Rev. 621, 626 (1947). See also Legislative History, supra note 67, at 125 (testimony of ICC Commissioner Aitchison before House Judiciary Subcommittee in June, 1945).

${ }^{70}$ See H.R. REp. No. 1980, 79th Cong., 2d Sess. 50 (1946), reprinted in LegisLative HistoRy, supra note 67, at 284. 
As so amended, this version of the publication requirement was enacted; it required publication of "substantive rules adopted as authorized by law and statements of general policy or interpretations formulated by the agency for the guidance of the public, but not rules addressed to and served upon named persons in accordance with law." The House Report explained that if all rules served on named individuals were published, the Federal Register would be filled "with a great mass of particularized rule making which has always been satisfactorily handled without general publication."72 Agencies were required, however, to make these rules available to the public. ${ }^{73}$ The Attorney General's contemporaneous explanation of the section notes that the provision was "designed to avoid filling the Federal Register with a great mass of particularized rule-making," such as rate schedules or advisory interpretations relating to specific situations. ${ }^{74}$ Thus, Congress intended the scope of the agency action, not its impact, to determine whether publication was required.

The addition of the "general applicability" language in 1966 to both the substantive-rule and interpretation clauses, and the corresponding deletion of the "named persons" language, does not change this conclusion; the Senate Report described this change as a technical one. ${ }^{25}$ In a report on an earlier version of the bill enacted in $1966,{ }^{78}$ the Senate Judiciary Committee discussed the insertion of the "general applicability" modifier, and stated:

${ }^{71}$ Administrative Procedure Act, ch. 324, § 3(a), 60 Stat. 238 (1946) (current version at 5 U.S.C. $\$ 552(a))$. For the full text of this provision, see note 53 supra.

${ }^{72}$ H.R. Rep. No. 1980, 79th Cong., 2d Sess. 50 n.6 (1946), reprinted in Legislative History, supra note 67 , at 284 . The original Senate bill did not include policy statements and interpretations in the provision's publication requirements. They were included, however, when the bill was reported to the Senate floor. Compare S. REP. No. 752, 79th Cong., 1st Sess. 12 (1945) with id. at 33. No explanation of the change was made.

${ }^{73}$ See note 53 supra. The House Report noted: "This change supplements the change explained in note 6. If some rules are not published in the Federal Register, then clearly they should be made available. . . " H.R. REP. No. 1980, 79th Cong., 2d Sess. 50 n.7 (1946), reprinted in Legislative HistoRy, supra note 67, at 284.

${ }^{74}$ U.S. Dep't of Justice, Attorney General's Manual on the Administrative ProceDURE ACT 22 (1947).

${ }^{75}$ S. REP. No. 813, 89th Cong., 1st Sess. 6 (1965). See also H.R. REP. No. 1497, 89th Cong., 2d Sess. 7 (1966) ("A number of minor changes . . . clarify . . . that the Federal Register is a publication in which the public can find the details of the administrative operations of Federal agencies."); AtToRney GenERAL's MEMorandum, supra note 49, at 10, reprinted in FOIA SOURCEBOOK, supra note 49, at 209.

${ }^{76}$ S. 1666, 88th Cong., 2d Sess. (1964). This bill was extremely similar to the one finally adopted. Freedom of Information Act, Pub. L. No. 89-487, 80 Stat. 250 (1966) (codified at 5 U.S.C. $\S 552(a)(1976)$ ). One difference between the two bills was that the former required 
In section 2 of the Administrative Procedure Act, rules are defined in such a way that there is no distinction between those of a particular applicability (such as rates) and those of general applicability. It is believed that only rules, statements of policy, and interpretations of general applicability should be published in the Federal Register; those of particular applicability or [sic] legion in number and have no place in the Federal Register and are presently excepted but by more cumbersome language. ${ }^{77}$

Congressional intent was unambiguous: interpretations and policy statements of general applicability were to be published, while those of particular applicability were to be available at agency offices. This distinction is not, however, without ambiguity. "Of particular applicability" might mean an interpretation or policy statement applicable only to named individuals-or it might mean an interpretation or policy statement substantively equivalent to adjudication rather than legislation. It is, therefore, necessary to determine which interpretation provides a principled test consistent with the intent of Congress.

\section{The Meaning of the General/Particular Distinction}

The legislative history of the APA suggests that Congress intended "general applicability" to be determined by a formal standard: whether the interpretation or policy statement is applicable only to named individuals. Moreover, the application of a standard that ignores form and instead turns on whether the interpretation or policy statement is in substance "of general applicability" would prove to be impractical and unprincipled.

\section{A. The Named-Persons Standard}

1. Legislative History. As originally enacted, section $552(a)(1)(D)$ required publication of all rules and interpretations except those "addressed to and served upon named persons."

the availability of "rules, statements of policy, and interpretations which have been adopted by the agency, affect the public and are not required to be published in the Federal Register." S. 1666, 88th Cong., 2d Sess. (1964) (emphasis added). The "affect the public" language was dropped when a modified version of the bill was introduced in the Senate. S. 1160,89 th Cong., 1st Sess. (1965).

${ }^{77}$ S. REP. No. 1219, 88th Cong., 2d Sess. 4 (1964), reprinted in FOIA SourcebooK, supra note 49 , at 89 .

78 See text and notes at notes 68-74 supra. 
though this standard was deleted in 1966, the legislative history indicates that the named-persons standard was always equivalent to the "of general applicability" standard. ${ }^{79}$

As discussed above, the named-persons exception was added to the original APA bill when the definition of rules was amended to include "agency statements" of "particular" as well as "general" applicability. ${ }^{80}$ The House Committee explained that the namedpersons exception was necessary to avoid publication of particularized rules. ${ }^{81}$ Thus, the named-persons standard was originally designed to track the general/particular distinction. ${ }^{82}$ Moreover, when Congress amended the publication provision in 1966, the substitution of the general applicability phrase for the named-persons exception was not intended to change the publication standard..$^{\text {s3 }}$

2. Evaluation of the Named-Persons Standard. A namedpersons standard has several advantages. It is a formal test that can be applied by the courts without difficulty, and agencies can easily determine in advance whether publication is necessary.

79 See text and notes at notes 75-77 supra.

${ }^{80}$ See text and notes at notes 68-70 supra.

si See text and note at note 72 supra.

${ }^{82}$ In a 1938 regulation concerning a publication requirement in the Federal Register Act, Pub. L. No. 74-220, ch. 417, § 5, 49 Stat. 501 (1935) (current version at 44 U.S.C. $\S 1505$ (1976)), "general applicability" seemed to be equated with a named-persons standard, 3 Fed. Reg. 2458 (1938). The regulation defined "general applicability" as "currently relevant or applicable to the general public, the members of a class, or the persons of a locality, as distinguished from named individuals or organizations." Id.

The publication requirement in the Federal Register Act is not, however, equivalent to the publication requirement in section $552(\mathrm{a})(1)(D)$. The former requires publication of certain documents "of general applicability and legal effect," while the latter requires publication only of certain documents "of general applicability." In United States v. Mowat, 582 F.2d 1194 (9th Cir.), cert. denied, 439 U.S. 967 (1978), the court confused the relation between the two statutes. In United States v. Aarons, 310 F.2d 341 (2d Cir. 1962), Judge Friendly correctly noted that the APA requires publication of additional material. Other courts have expressed awareness of a possible relation without addressing the issue. See, e.g., Aiken v. Obledo, 442 F. Supp. 628, 654 n.15 (E.D. Cal. 1977); Anderson v. Butz, 428 F. Supp. 245, 250 n.8 (E.D. Cal.), aff'd, 550 F.2d 549 (9th Cir. 1977).

${ }^{83}$ See text and note at note 75 supra. Professor Davis has stated that the legislative history of the "general applicability" term provides no assistance in understanding the scope of the publication requirement. K. Davis, Administrative Law Treatise 125 (Supp. 1970); Davis, The Information Act: A Preliminary Analysis, 34 U. CHI. L. REv. 761, 769 (1967). Two paragraphs before concluding that the legislative history is unhelpful, however, Professor Davis states that the named-persons exception was "adequately expressed by the words 'of general applicability." "K. DAvis, supra, at 125 n.22; Davis, supra, at 768 n.22. It is difficult to understand how the legislative history can be of no assistance in determining the meaning of "general applicability" when that history indicates that general applicability was intended to be equivalent to the named-persons standard. 
Moreover, the distinction incorporated in this test, although formal, is not arbitrary. Interpretations and policy statements addressed to named persons will not usually be intended to set broad agency standards equally relevant to other individuals. Interpretations and policy statements not addressed to named persons are more likely, however, to state broad agency standards "of general applicability." Indeed, on its face, such a pronouncement can be regarded as "of general applicability" because it is not addressed to only named individuals.

The distinction between named and unnamed interpretations and policy statements resembles the distinction between adjudication and legislation. Although laws purport to set broad policies, cases purport only to apply law to the factual situation presented by the particular litigants. There may be strong policy reasons for requiring the publication of all interpretations and policy statements; an interpretation addressed to a specific individual may well influence future agency pronouncements in similar fact situations. There is no logical inconsistency, however, in requiring publication of legislation-like agency pronouncements but not adjudication-like pronouncements.

Since the named-persons standard is a formal test of the general/particular distinction, it suffers from two weaknesses. First, an agency can evade the publication requirement merely by addressing a pronouncement to specific individuals. Second, the test will only tend to identify correctly those agency pronouncements likely to be "of general applicability." For example, a new and broad statement of agency policy may be incorporated in a letter responding to an inquiry from a single individual. The policy is not less "general" in its scope because the letter is addressed to a single individual.

Although both the Senate and House Reports referred to the 1966 amendment of section 552(a)(1) as "technical,"84 the new language, "of general applicability," is arguably less restrictive than the original wording, "served on named persons in compliance with the law." Thus, it may be argued that Congress intended some change in the formality of the publication standard. The 1966 amendment may indicate a shift from a purely formal standard to a more substantive one distinguishing between those agency actions that resemble adjudications and are limited in their scope, 
and those that resemble legislation and are "of general applicability."

\section{B. A Substantive Standard}

A substantive standard would be designed to identify directly those agency pronouncements that are "of general applicability" regardless of their form. Under such a standard, agencies would not be able to evade the publication requirement by controlling the form of the agency pronouncement. Moreover, the standard would correspond to the intent of Congress in requiring publication of agency pronouncements "of general applicability." Unfortunately, the weakness of this standard becomes apparent when an attempt is made to identify precisely what it is that makes an agency interpretation or policy statement "of general applicability."

1. The Legislation/Adjudication Distinction. As discussed above, those agency pronouncements that are more like legislation than adjudication might be considered "of general applicability." Those agency pronouncements that merely apply existing law or are based on the resolution of legal issues rather than policy decisions might be considered more like adjudication than legislation. Each of these distinctions breaks down, however, under closer scrutiny.

The application-of-existing-law distinction is based on the proposition that agency interpretations or policy statements that only apply existing law are not "of general applicability." This proposition is untenable for two reasons. First, it merely restates the significant-impact test. As is true of other formulations of the significant-impact test, there is no logical relationship between scope of applicability and whether an interpretation or policy statement applies existing law. Second, this standard would be impossible to administer. An agency would have to examine every agency pronouncement to determine whether it applied or extended existing statutes, published rules, interpretations, or policy statements.

The law/policy distinction is based on the premise that those agency actions that are more like legislation than adjudication because they are basically policy decisions are "of general applicability," and that those actions that are more like adjudication because they are basically legal decisions are not "of general applicability." Yet no such correlation exists. Legal decisions often establish rules of general applicability, while policy decisions may be extremely limited in scope. 
The application-of-existing-law and law/policy distinctions thus fail to provide an adequate theoretical foundation for the legislation/adjudication distinction suggested by the "general applicability" phrase. And, given the failure of the APA substantively to distinguish adjudication from rulemaking, ${ }^{88}$ any attempt to rest determinations of "general applicability" on a substantive distinction between adjudication and legislation is likely to fail. Under the APA, an agency is free to develop all principles, interpretations, and policies through adjudication..$^{86}$ Although the distinction between rulemaking and adjudication is central to the APA, ${ }^{87}$ the distinction is made in only a purely formal and conclusory manner. ${ }^{88}$

2. The Many/Few Distinction. Perhaps an agency pronouncement is not "of general applicability" when it is applicable to only a few individuals. ${ }^{89}$ If those individuals are named in the pronouncement and receive copies of it, this test is merely a restatement of the named-persons standard. If this standard does not require that the "few" individuals to whom it is addressed be named and receive copies of the pronouncement, it is necessary to determine how many unnamed individuals constitute a few. Whether the pronouncement is applicable to only a discrete group cannot be determinative since most, if not all, interpretations and policy statements will apply to less than all individuals. This version of a substantive standard would, therefore, require that courts decide on an ad hoc, after-the-fact basis whether or not an agency

ss See Scalia, Vermont Yankee: The APA, the D.C. Circuit, and the Supreme Court, 1978 SUP. CT. REv. 345, 383 ("it is generally acknowledged that the only responsible judicial attitude toward this central APA definition is one of benign disregard").

so See, e.g., NLRB v. Bell Aerospace Co., 416 U.S. 267, 294-95 (1974).

${ }^{87} \mathrm{~K}$. Davis, Administrative Law Treatise 294-97 (1958).

so Compare 5 U.S.C. § 551(5) (1976) (" 'rulemaking' means agency process for formulating, amending, or repealing a rule") with id. §551(7) ("'adjudication' means agency process for the formulation of an order").

* This standard was approved in Note, The Freedom of Information Act: Access to Law, 36 Fordham L. Rev. 765 (1968), an early criticism of Professor Davis's approach. The author suggested:

If a standard will in fact be applicable to a large number of persons, in the public at large or within an identifiable class, then it is general. If it has an adversarial flavor and is directed, either expressly or in fact, at a small number within a class, then it is not general.

Id. at 774. The Note did not rely on the legislative history of section $552(\mathrm{a})(1)(\mathrm{D})$ to support this formulation, but argued instead by analogy to the rulemaking/adjudication distinction. Id. at 771 . 
pronouncement is applicable to so few individuals that publication is unnecessary.

This standard is less desirable than the named-persons standard. The many/few distinction cannot give agencies clear guidance as to which pronouncements should be published. Even after a coherent body of case law develops as to the meaning of the standard, the agency often will not know how many individuals, other than addressees, are within the scope of an interpretation, rule, or policy. If, for example, the IRS receives a request for a private letter ruling on the tax treatment of a particular corporate transaction, it may be unable to determine whether its answer is applicable to only a "few." The administrative difficulties created by the many/few distinction, combined with the substantial overlap between the many/few and the named-persons standards, ${ }^{80}$ indicate that it would be inappropriate to deviate from the standard specifically created by Congress: the named-persons standard.

\section{CONCLUSION}

This comment has argued that the need for publication under section $552(a)(1)(D)$ should be determined by reference to the statutory language rather than the significant-impact test. Not only is the significant-impact test inconsistent with the language of the statute, its use has created other problems of statutory meaning and consistency. Moreover, there is evidence that Congress did not intend to impose a significant-impact test when it used the word "general" and the phrase "of general applicability." Finally, the legislative history indicates that Congress did mean to require publication of interpretations and policy statements that are "general" rather than "particular." Analysis of the possible meanings of this distinction and the relevant legislative history indicates that courts should require publication of interpretations and policy statements not addressed to named persons.

Victor H. Polk, Jr.

${ }^{80}$ One would expect that agency pronouncements directed to named persons would apply only to a few individuals. Conversely, agency statements relevant to only a few individuals should be specifically directed to those named persons. 